\title{
Determination of Coconut Oil Adulteration with Soybean Oil by Direct Infusion Electrospray Ionization Mass Spectrometry
}

\author{
Jessica S. Pizzo, ${ }^{\oplus a}$ Marília B. Galuch, ${ }^{\oplus a}$ Patrícia D. S. Santos, ${ }^{a}$ Luciana P. Manin, ${ }^{\oplus b}$ \\ Caroline D. Zappielo, ${ }^{\circledR a}$ Orivaldo J. Silva Filho, ${ }^{a}$ Oscar O. Santos ${ }^{\circledR b}$ and Jesuí V. Visentainer $^{*, a}$ \\ ${ }^{a}$ Departamento de Química, Universidade Estadual de Maringá (UEM), \\ 87020-900 Maringá-PR, Brazil \\ ${ }^{b}$ Programa de Pós-Graduação em Ciência de Alimentos, Universidade Estadual de Maringá \\ (UEM), 87020-900 Maringá-PR, Brazil
}

\begin{abstract}
Coconut oil has several domestic uses and health benefits, which can be used in food, pharmaceuticals and cosmetics products. However, it has been the target of adulteration with lower price oils and fats, such as soybean oil. In this study, a fast, easy and simple methodology was used to detect low quantities of intentionally adulterated coconut oil with soybean oil by direct infusion electrospray ionization mass spectrometry (ESI-MS) at different levels $(0,2,5,10,15,20,30,50$, 70 and $100 \%$ ). In the oil industry, intentional adulterations usually occur with the addition of low quantities of soybean oil to coconut oil. Therefore, the suggested ESI-MS method is promising for routine analysis to guarantee the quality control of coconut oil since it is possible to detect adulteration with a minimal of $2 \%$ soybean oil addition.
\end{abstract}

Keywords: lipid profile, coconut oil, direct infusion, mass spectrometry, adulteration

\section{Introduction}

Coconut oil is a vegetable oil obtained from the fruit of the Cocos nucifera $\mathrm{L}$. palm tree. The oil is extracted from copra, the dried coconut meat (endosperm) ${ }^{1}$ that contains about $65-75 \%$ of oil. ${ }^{2}$ Coconut oil presents high percentage of saturated oil (90\%). In addition, it is composed for medium chain fatty acid (approximately $60 \%$ of total fatty acid composition), ${ }^{3}$ principally the lauric acid (12:0). ${ }^{4}$

Coconut oil is widely consumed in domestic use ${ }^{1}$ and it also can be used in food, pharmaceuticals and cosmetics products, ${ }^{5}$ as skin moisturizer and insect repellant, besides being effective against a variety of viruses. ${ }^{1}$ Among all its properties, antithrombotic, bactericidal activity and antiseptic effects stand out.

Due to its pleasant flavor and beneficial properties, the price of coconut oil on the market is one of the highest among common vegetable oils. So, it has been the target of adulteration with lower price vegetable oils and fats, ${ }^{6}$ such as soybean oil. ${ }^{7}$ Brazil is the world's second largest soybean producer and the soybean grain is cheap in this

*e-mail: jesuiv@gmail.com country. ${ }^{8}$ Therefore, intentional adulterations using this oil are common. ${ }^{9-11}$

In recent times, several analytical methods have been developed in order to monitoring adulterants in coconut oil, such as Fourier transform infrared spectroscopy, ${ }^{12,13}$ differential scanning calorimetry, ${ }^{12,14}$ and a sensor for an electronic noise system. ${ }^{15}$ However, some of these methods are too laborious. Therefore, fast and accurate methods must be developed to detect and quantify adulterations in coconut oil.

Mass spectrometry is a fast, sensitive and selective technique, and it has been successfully used for the characterization of oil matrices; moreover, both of lipid profiles and lipid markers can be monitored in order to verify adulteration..$^{10,11,16,17}$ More specifically, direct infusion by electrospray ionization mass spectrometry (ESI-MS) has been used due to its advantages, such as speed and simplicity during the analysis and in the preparation of the sample (minor or no preparation). ${ }^{18}$

Recently, an ESI-MS method was employed to identify and quantify the olive oil adulteration by soybean oil, monitoring a particular lipid marker, a triacylglycerol (TAG), that is present only in soybean oil. ${ }^{11}$ However, to the best of our knowledge, ESI-MS has not been employed 
yet in order to identify and quantify the addition of soybean oil in coconut oil.

The aim of this work was to identify and quantify intentionally additions of soybean oil to coconut oil using their ESI-MS lipid profiles, by monitoring a specific lipid marker (TAG) which is present only in soybean oil. The lipid marker-ESI-MS method was applied in five coconut oil samples in order to quantify possible additions of soybean oil. Besides, the fatty acid composition of pure and mixed coconut and soybean oils via gas chromatography with flame ionization detection (GC-FID) were obtained, in order to compare its results with those obtained by the proposed ESI-MS method.

\section{Experimental}

\section{Samples}

To obtain pure coconut oil (CNO), coconut was purchased from a local market in Maringá (Paraná, Brazil). Soybean oil (SOO) and five different brands of extra virgin coconut oil (label declared as pure) were acquired in the same region. The commercial coconut oil samples were coded as $\mathrm{C} 1, \mathrm{C} 2, \mathrm{C} 3, \mathrm{C} 4$ and $\mathrm{C} 5$.

\section{Obtaining pure coconut oil (CNO)}

Coconut pulp was removed and homogenized. Then, the $\mathrm{CNO}$ was extracted based on Bligh and Dyer. ${ }^{19}$ Initially, $45.0 \mathrm{~mL}$ of a solution of chloroform/methanol $(1: 2 \mathrm{v} / \mathrm{v})$ was added in $15.0 \mathrm{~g}$ of CNO. The mixture was homogenized under magnetic stirring for $5 \mathrm{~min}$, followed by the addition of $15.0 \mathrm{~mL}$ of chloroform and stirring for $2 \mathrm{~min}$. After, $15.0 \mathrm{~mL}$ of distilled water was added to the mixture and it was stirred for $5 \mathrm{~min}$. Then, the solution was filtered under vacuum on a Büchner funnel with filter paper (Whatman No. 1) and the filtrate solution was transferred to a separating funnel.

After separation, the organic phase (lower phase, containing the lipids) was collected, and the solvent was evaporated in a rotator evaporator (Fisatom, Brazil). The oil was collected and stored at $-18{ }^{\circ} \mathrm{C}$ for further analysis. This oil was used as the reference for pure CNO.

\section{Gas chromatographic analysis of fatty acid}

Fatty acid composition of the samples was determined via GC-FID. Primarily, the esterification of fatty acids to fatty acid methyl esters (FAMEs) were carried out according to method described by Hartman and $\operatorname{Lago}^{20}$ and modified by Maia and Rodriguez-Amaya. ${ }^{21}$
Chromatographic analysis was performed using a Trace Ultra 3300 Thermo Scientific gas chromatograph (GC) fitted with a flame ionization detector (FID), a capillary column (fused silica CP-7420, select FAME, $100.0 \mathrm{~m} \times 0.25 \mathrm{~mm} \times 0.25 \mu \mathrm{m}$ of cyanopropyl), and split/ splitless injector. Samples were injected $(1.0 \mu \mathrm{L})$ using split mode with a 40:1 ratio. The operation parameters were as follows: column temperature, $165^{\circ} \mathrm{C}$ for $18 \mathrm{~min}$, programmed to increase at $4{ }^{\circ} \mathrm{C} \mathrm{min}{ }^{-1}$ to $235^{\circ} \mathrm{C}$ and kept at this temperature for $20 \mathrm{~min}$. The gas flows used were the following: $1.2 \mathrm{~mL} \mathrm{~min}{ }^{-1}$ carrier gas $\left(\mathrm{H}_{2}\right) ; 30 \mathrm{~mL} \mathrm{~min}^{-1}$

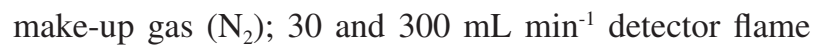
gases $\left(\mathrm{H}_{2}\right.$ and synthetic air, respectively). Detector and injector temperatures were maintained at 250 and $230^{\circ} \mathrm{C}$, respectively. For identification, FAMEs retention times were compared with relative analytical standards methyl esters, FAME-Mix (Sigma-Aldrich, USA). The relative percent of total fatty acids were automatically computed by ChromQuest ${ }^{\mathrm{TM}} 5.0$ software.

\section{Lipid marker-ESI(+)-MS method}

The lipid samples were prepared according to Silveira et al. ${ }^{11} 50.0 \mu \mathrm{L}$ of oil was dissolved in $950.0 \mu \mathrm{L}$ of chloroform (Synth, Brazil). Then, $5.0 \mu \mathrm{L}$ of this solution was transferred to another vial and it was diluted with $1.0 \mathrm{~mL}$ of 9:1 (v/v) methanol/chloroform solution (HPLC grade, J. T. Baker $^{\circledR}$, USA). $20.0 \mu \mathrm{L}$ of a ammonium formate (SigmaAldrich, Germany) solution $\left(0.10 \mathrm{~mol} \mathrm{~L}^{-1}\right.$ in methanol) was added in the final solution, in order to monitor the TAG in the ammonium adduct form, $\left[\mathrm{TAG}+\mathrm{NH}_{4}\right]^{+}$.

The prepared solutions were directly infused $\left(10.0 \mu \mathrm{L} \mathrm{min}{ }^{-1}\right)$ in a Xevo TQ-D ${ }^{\mathrm{TM}}$ mass spectrometer (Waters, USA) fitted with an electrospray ionization source (ESI), operating in positive mode (+), using the following conditions: source temperature of $150{ }^{\circ} \mathrm{C}$; desolvation temperature of $200{ }^{\circ} \mathrm{C}$; desolvation gas flow of $500 \mathrm{~L} \mathrm{~h}^{-1}$; cone voltage of $20.0 \mathrm{~V}$ and capillary voltage of $3.00 \mathrm{kV}$ based on Galuch et al. ${ }^{10}$ The mass/charge range of ESI-MS was $100-1200 \mathrm{~m} / z$. Data was processed using MassLynx ${ }^{\mathrm{TM}}$ software. All solutions were infused in triplicate.

In order to quantify possible adulterations of commercial coconut oil samples, a calibration curve equation was obtained by linear regression, through the graph of the intensity of the selected lipid marker $\left(870.9 \mathrm{~m} / z\left[\mathrm{TAG}+\mathrm{NH}_{4}\right]^{+}\right.$, present only in SOO) versus percentage of SOO added to $\mathrm{CNO}(0,2,5$, $10,15,20,30,50,70$ and $100 \%)$.

\section{Statistical analysis}

The relative percentages of the fatty acid composition 
obtained by GC-FID were submitted to variance analysis (ANOVA) and the means values were compared by Tukey's test (95\% of confidence) using PAST3 software. ${ }^{22}$

\section{Results and Discussion}

\section{Fatty acid by GC-FID}

Table 1 presents the reference range of fatty acid composition of authentic vegetable oils according to the Codex Standard for Named Vegetable Oils (CX-STAN 21-1999, amended in 2015), ${ }^{23}$ as well as the fatty acid compositions obtained for the pure $\mathrm{CNO}$, commercial coconut oil samples (C1, C2, C3, C4 and C5), and SOO.

From Table 1, the fatty acid composition of CNO and C1-C5 samples were in accordance with the Codex Alimentarius. ${ }^{23}$ The fatty acid composition of SOO was also in accordance with these standards. Moreover, the results of $\mathrm{CNO}$ and $\mathrm{C} 1-\mathrm{C} 5$ were in accordance with those obtained by Aued-Pimentel et al. ${ }^{7}$

Saturated fatty acids were found predominantly in $\mathrm{CNO}$ and $\mathrm{C} 1-\mathrm{C} 5$. In CNO and C1-C5, lauric acid (12:0) was the most abundant saturated fatty acid, ranging from
48.82-53.66\%. The monounsaturated oleic acid (18:1) was found in the range of $3.66-5.76 \%$, and the polyunsaturated linoleic acid (18:2) was found from $0.65-1.48 \%$. However, the polyunsaturated linoleic acid was found predominantly in SOO (53.26\%).

Table 2 presents CNO intentionally adulterated with the addition of 1, 2, 3, 5, 7, and 10\% SOO.

Fatty acid by GC-FID usually is used to characterize vegetable oils and, consequently, can detect crude fraud. However only this analysis not ensure the vegetable oil was adulterated in small quantities. ${ }^{11}$

From Table 2, fatty acid percentages outside the reference range for coconut oil can be observed from intentionally addition of $2 \%$ of SOO in CNO for capric acid (10:0), lauric acid (12:0), palmitic acid (16:0), stearic acid (18:0) and linoleic acid (18:2).

However, it was only possible to observe changes from $7 \%$ of intentionally addition of SOO for the caprylic acid (8:0) and oleic acid (18:1). By monitoring the myristic acid (14:0), it was not possible to notice any adulteration, since its percentages were kept inside the range established by the Codex Alimentarius ${ }^{23}$ in every intentionally addition. In addition, soybean oil is a linolenic acid (18:3) source, ${ }^{24,25}$

Table 1. Fatty acid composition of pure coconut oil (CNO), soybean oil (SOO) and commercial coconut oil samples, samples (C1-C5), and the reference range of authentic oils

Fatty acid composition ${ }^{\mathrm{a}} / \%$

\begin{tabular}{|c|c|c|c|c|c|c|c|c|c|}
\hline Fatty acid & $\mathrm{C} 1$ & $\mathrm{C} 2$ & $\mathrm{C} 3$ & $\mathrm{C} 4$ & C5 & $\mathrm{CNO}$ & $\begin{array}{l}\text { Coconut oil } \\
\text { Codex } \\
\text { Alimentarius }^{\mathrm{b}}\end{array}$ & $\mathrm{SOO}$ & $\begin{array}{l}\text { Soybean oil } \\
\text { Codex } \\
\text { Alimentarius }^{\text {b }}\end{array}$ \\
\hline $6: 0$ & $\mathrm{ND}^{\mathrm{A}}$ & $\mathrm{ND}^{\mathrm{A}}$ & $\mathrm{ND}^{\mathrm{A}}$ & $\mathrm{ND}^{\mathrm{A}}$ & $\mathrm{ND}^{\mathrm{A}}$ & $\mathrm{ND}^{\mathrm{A}}$ & ND-0.7 & $\mathrm{ND}^{\mathrm{A}}$ & ND \\
\hline $8: 0$ & $8.50 \pm 0.28^{\mathrm{A}}$ & $7.80 \pm 0.05^{\mathrm{AB}}$ & $6.54 \pm 0.02^{\mathrm{C}}$ & $8.66 \pm 0.09^{\mathrm{AB}}$ & $7.04 \pm 0.17^{\mathrm{BCD}}$ & $7.19 \pm 0.78^{\mathrm{BCD}}$ & $4.6-10.0$ & $\mathrm{ND}^{\mathrm{E}}$ & ND \\
\hline $10: 0$ & $7.36 \pm 0.13^{\mathrm{A}}$ & $6.88 \pm 0.07^{\mathrm{AB}}$ & $5.41 \pm 0.09^{\mathrm{C}}$ & $7.39 \pm 0.08^{\mathrm{AB}}$ & $5.57 \pm 0.04^{\mathrm{CD}}$ & $5.97 \pm 0.36^{\mathrm{CD}}$ & $5.0-8.0$ & $\mathrm{ND}^{\mathrm{E}}$ & ND \\
\hline $12: 0$ & $53.16 \pm 0.52^{\mathrm{A}}$ & $52.35 \pm 0.60^{\mathrm{AB}}$ & $49.05 \pm 0.25^{\mathrm{C}}$ & $53.66 \pm 0.21^{\mathrm{AB}}$ & $48.82 \pm 0.07^{\mathrm{CD}}$ & $49.89 \pm 1.08^{\mathrm{CD}}$ & $45.1-53.2$ & $\mathrm{ND}^{\mathrm{E}}$ & ND-0.1 \\
\hline $14: 0$ & $17.45 \pm 0.39^{\mathrm{D}}$ & $18.12 \pm 0.06^{\mathrm{CD}}$ & $21.04 \pm 0.02^{\mathrm{A}}$ & $17.21 \pm 0.13^{\mathrm{CD}}$ & $20.59 \pm 0.04^{\mathrm{AB}}$ & $19.80 \pm 0.73^{\mathrm{AB}}$ & $16.8-21.0$ & $\mathrm{ND}^{\mathrm{E}}$ & ND-0.2 \\
\hline $16: 0$ & $6.79 \pm 0.24^{\mathrm{E}}$ & $7.45 \pm 0.25^{\mathrm{DE}}$ & $8.58 \pm 0.13^{\mathrm{B}}$ & $6.53 \pm 0.10^{\mathrm{DE}}$ & $8.27 \pm 0.03 \mathrm{~B}^{\mathrm{CD}}$ & $8.41 \pm 0.74^{\mathrm{BCD}}$ & $7.5-10.2$ & $11.15 \pm 0.09^{\mathrm{A}}$ & $8.0-13.5$ \\
\hline $16: 1$ & $\mathrm{ND}^{\mathrm{B}}$ & $\mathrm{ND}^{\mathrm{B}}$ & $\mathrm{ND}^{\mathrm{B}}$ & $\mathrm{ND}^{\mathrm{B}}$ & $\mathrm{ND}^{\mathrm{B}}$ & $\mathrm{ND}^{\mathrm{B}}$ & $\mathrm{ND}^{\mathrm{B}}$ & $0.08 \pm 0.01^{\mathrm{A}}$ & ND-0.2 \\
\hline $17: 0$ & $\mathrm{ND}^{\mathrm{B}}$ & $\mathrm{ND}^{\mathrm{B}}$ & $\mathrm{ND}^{\mathrm{B}}$ & $\mathrm{ND}^{\mathrm{B}}$ & $\mathrm{ND}^{\mathrm{B}}$ & $\mathrm{ND}^{\mathrm{B}}$ & $\mathrm{ND}^{\mathrm{B}}$ & $0.08 \pm 0.02^{\mathrm{A}}$ & ND-0.1 \\
\hline $17: 1$ & $\mathrm{ND}^{\mathrm{B}}$ & $\mathrm{ND}^{\mathrm{B}}$ & $\mathrm{ND}^{\mathrm{B}}$ & $\mathrm{ND}^{\mathrm{B}}$ & $\mathrm{ND}^{\mathrm{B}}$ & $\mathrm{ND}^{\mathrm{B}}$ & $\mathrm{ND}^{\mathrm{B}}$ & $0.04 \pm 0.01^{\mathrm{A}}$ & ND-0.1 \\
\hline $18: 0$ & $2.32 \pm 0.10^{\mathrm{D}}$ & $2.53 \pm 0.19^{\mathrm{CD}}$ & $2.80 \pm 0.05^{\mathrm{BC}}$ & $2.23 \pm 0.05^{\mathrm{CDF}}$ & $2.46 \pm 0.03^{\mathrm{BCDE}}$ & $2.26 \pm 0.25^{\mathrm{CDE}}$ & $2.0-4.0$ & $4.24 \pm 0.10^{\mathrm{A}}$ & $2.0-5.4$ \\
\hline $18: 1$ & $3.77 \pm 0.14^{\mathrm{E}}$ & $4.21 \pm 0.22^{\mathrm{DE}}$ & $5.45 \pm 0.21^{\mathrm{C}}$ & $3.66 \pm 0.06^{\mathrm{DE}}$ & $5.76 \pm 0.05^{\mathrm{BC}}$ & $5.15 \pm 0.42^{\mathrm{BC}}$ & $5.0-10.0$ & $25.13 \pm 0.13^{\mathrm{A}}$ & $17-30$ \\
\hline $18: 2$ & $0.65 \pm 0.02^{\mathrm{E}}$ & $0.66 \pm 0.02^{\mathrm{DE}}$ & $1.12 \pm 0.02^{\mathrm{C}}$ & $0.66 \pm 0.01^{\mathrm{DE}}$ & $1.48 \pm 0.02^{\mathrm{B}}$ & $1.33 \pm 0.09^{\mathrm{BC}}$ & $1.0-2.5$ & $53.26 \pm 0.24^{\mathrm{A}}$ & $48.0-59.0$ \\
\hline $18: 3$ & $\mathrm{ND}^{\mathrm{B}}$ & $\mathrm{ND}^{\mathrm{B}}$ & $\mathrm{ND}^{\mathrm{B}}$ & $\mathrm{ND}^{\mathrm{B}}$ & $\mathrm{ND}^{\mathrm{B}}$ & $\mathrm{ND}^{\mathrm{B}}$ & ND-0.2 & $5.35 \pm 0.11^{\mathrm{A}}$ & $4.5-11.0$ \\
\hline $20: 0$ & $\mathrm{ND}^{\mathrm{B}}$ & $\mathrm{ND}^{\mathrm{B}}$ & $\mathrm{ND}^{\mathrm{B}}$ & $\mathrm{ND}^{\mathrm{B}}$ & $\mathrm{ND}^{\mathrm{B}}$ & $\mathrm{ND}^{\mathrm{B}}$ & ND-0.2 & $0.29 \pm 0.01^{\mathrm{A}}$ & $0.1-0.6$ \\
\hline $20: 1$ & $\mathrm{ND}^{\mathrm{B}}$ & $\mathrm{ND}^{\mathrm{B}}$ & $\mathrm{ND}^{\mathrm{B}}$ & $\mathrm{ND}^{\mathrm{B}}$ & $\mathrm{ND}^{\mathrm{B}}$ & $\mathrm{ND}^{\mathrm{B}}$ & ND-0.2 & $0.38 \pm 0.04^{\mathrm{A}}$ & ND-0.5 \\
\hline
\end{tabular}

${ }^{a}$ Results were expressed as mean \pm standard deviation of three replicates. Values with same uppercase letters in the same line are significantly the same $(p<0.05)$ by Tukey's test; 'bange of authentic coconut oil. ${ }^{23}$ SOO: soybean oil; CNO: pure coconut oil; C1-C5: commercial coconut oil samples; fatty acids composition: caproic acid (6:0); caprylic acid (8:0); capric acid (10:0); lauric acid (12:0); myristic acid (14:0); palmitic acid (16:0); palmitoleic acid (16:1); margaric acid (17:0); heptadecenoic acid (17:1); stearic acid (18:0); oleic acid (18:1); linoleic acid (18:2); linolenic acid (18:3); arachidic acid (20:0); eicosenoic acid (20:1); ND: not detected. 
Table 2. Fatty acids composition by GC-FID of pure coconut oil (CNO) intentionally adulterated with the addition of soybean oil (SOO)

\begin{tabular}{|c|c|c|c|c|c|c|c|}
\hline \multirow[b]{2}{*}{ Fatty acid } & \multicolumn{7}{|c|}{ Fatty acid composition ${ }^{\mathrm{a}} / \%$} \\
\hline & $\mathrm{CNO}$ & $2 \%$ of SOO & $3 \%$ of SOO & $5 \%$ of SOO & $7 \%$ of SOO & $10 \%$ of SOO & $\begin{array}{l}\text { Coconut oil } \\
\text { Codex } \\
\text { Alimentarius }^{\mathrm{b}}\end{array}$ \\
\hline 8:0 & $7.19 \pm 0.78^{\mathrm{A}}$ & $5.46 \pm 0.10^{\mathrm{BC}}$ & $6.75 \pm 0.35^{\mathrm{A}}$ & $5.15 \pm 0.21^{\mathrm{BC}}$ & $3.16 \pm 0.04^{\mathrm{D}}$ & $2.99 \pm 0.06^{\mathrm{D}}$ & $4.6-10.0$ \\
\hline 10:0 & $5.97 \pm 0.36^{\mathrm{A}}$ & $4.47 \pm 0.35^{\mathrm{BC}}$ & $5.06 \pm 0.21^{\mathrm{BC}}$ & $4.08 \pm 0.10^{\mathrm{BC}}$ & $2.92 \pm 0.02^{\mathrm{D}}$ & $3.17 \pm 0.01^{\mathrm{D}}$ & $5.0-8.0$ \\
\hline $12: 0$ & $49.89 \pm 1.08^{\mathrm{A}}$ & $38.47 \pm 0.23^{\mathrm{C}}$ & $40.42 \pm 1.02^{\mathrm{C}}$ & $37.83 \pm 0.27^{\mathrm{D}}$ & $35.40 \pm 0.31^{\mathrm{E}}$ & $37.69 \pm 0.13^{\mathrm{CD}}$ & $45.1-53.2$ \\
\hline $14: 0$ & $19.80 \pm 0.73^{\mathrm{B}}$ & $19.31 \pm 0.23^{\mathrm{AB}}$ & $19.78 \pm 0.58^{\mathrm{AB}}$ & $20.11 \pm 0.84^{\mathrm{AB}}$ & $20.25 \pm 0.14^{\mathrm{AB}}$ & $18.92 \pm 0.05^{\mathrm{A}}$ & $16.8-21.0$ \\
\hline $16: 0$ & $8.41 \pm 0.74^{\mathrm{F}}$ & $12.20 \pm 0.19^{\mathrm{B}}$ & $11.17 \pm 0.65^{\mathrm{BDE}}$ & $12.00 \pm 0.01^{\mathrm{BCD}}$ & $12.79 \pm 0.11^{\mathrm{ABC}}$ & $11.80 \pm 0.08^{\mathrm{ABCD}}$ & $7.5-10.2$ \\
\hline 18:0 & $2.26 \pm 0.25^{\mathrm{E}}$ & $5.10 \pm 0.08^{\mathrm{A}}$ & $3.16 \pm 0.18^{\mathrm{CD}}$ & $3.69 \pm 0.13^{\mathrm{B}}$ & $4.08 \pm 0.00^{\mathrm{B}}$ & $3.59 \pm 0.02^{\mathrm{BC}}$ & $2.0-4.0$ \\
\hline $18: 1$ & $5.15 \pm 0.42^{\mathrm{D}}$ & $9.42 \pm 0.20^{\mathrm{B}}$ & $8.28 \pm 0.59^{\mathrm{c}}$ & $9.40 \pm 0.23^{\mathrm{B}}$ & $10.78 \pm 0.10^{\mathrm{A}}$ & $10.53 \pm 0.07^{\mathrm{A}}$ & $5.0-10.0$ \\
\hline $18: 2$ & $1.33 \pm 0.09^{\mathrm{E}}$ & $5.80 \pm 0.03^{\mathrm{C}}$ & $5.38 \pm 0.44^{\mathrm{C}}$ & $7.52 \pm 0.07^{\mathrm{B}}$ & $9.88 \pm 0.03^{\mathrm{A}}$ & $10.46 \pm 0.00^{\mathrm{A}}$ & $1.0-2.5$ \\
\hline $18: 3$ & $\mathrm{ND}^{\mathrm{D}}$ & $\mathrm{ND}^{\mathrm{D}}$ & $\mathrm{ND}^{\mathrm{D}}$ & $0.37 \pm 0.04^{\mathrm{C}}$ & $0.75 \pm 0.01^{\mathrm{B}}$ & $0.84 \pm 0.01^{\mathrm{A}}$ & ND-0.2 \\
\hline
\end{tabular}

aResults expressed as the mean \pm standard deviation of three replicates. Values with same uppercase letters in the same line are significantly the same $(p<0.05)$ by Tukey's test; ${ }^{b}$ range of authentic coconut oil. ${ }^{23}$ SOO: soybean oil; CNO: pure coconut oil; fatty acid composition: caprylic acid (8:0); capric acid (10:0); lauric acid (12:0); myristic acid (14:0); palmitic acid (16:0); stearic acid (18:0); oleic acid (18:1); linoleic acid (18:2); linolenic acid (18:3); ND: not detected.

but it was only possible to detect this fatty acid in $\mathrm{CNO}$ in additions of 5, 7 and $10 \%$ of SOO.

So, the evaluation of $\mathrm{CNO}$ adulteration with $\mathrm{SOO}$ by solely monitoring the fatty acid percentage by GC-FID was not conclusive. Therefore, complementary analyses should be performed.

\section{Lipid marker-ESI(+)-MS analysis}

ESI(+)-MS method is fast, selective, sensitive and simple, and little sample preparation is necessary. It has been used in the characterization of vegetable oils and fats and, consequently, can detect and/or quantify adulteration. ${ }^{10,11,16,26}$

The major constituent of vegetable oils is TAG. ${ }^{27}$ As seen in Table 3, TAGs of CNO were identified and the main individual TAG was LaLaLa, followed by CLaLa, CCLa, LaLaM and LaMM. (These symbols are TAGs standard, where C: capric acid, M: myristic acid and La: lauric acid). These results are according to DebMandal and Mandal. ${ }^{2}$ In Table 3, the ion peaks were described in relative percentages in which the most intense ion peak (LaLaLa) was assigned as $100 \%$.

Figure 1 presents the lipid profile of pure $\mathrm{CNO}$ and SOO comprising the spectra in the region of $100-1150 \mathrm{~m} / \mathrm{z}$. From Figure 1, the differences between their lipid profiles can be seen.

From their lipid profiles (Figure 1), the $\left[\mathrm{TAG}+\mathrm{NH}_{4}\right]^{+}$of $870.9 \mathrm{~m} / \mathrm{z}$ was selected as a SOO-lipid marker, since it was present only in SOO. In order to identify this lipid marker, its fragmentation was performed, once the fragmentation
Table 3. Relative abundances of the major $\left[\mathrm{TAG}+\mathrm{NH}_{4}\right]^{+}$detected by $\mathrm{ESI}(+)-\mathrm{MS}$ for coconut oil (CNO)

\begin{tabular}{lcccc}
\hline TAG $^{\mathrm{a}}$ & Composition & {$\left[\mathrm{TAG}+\mathrm{NH}_{4}\right]^{+} / \%$} & $\mathrm{CN} / \mathrm{DB}^{\mathrm{b}}$ & $\mathrm{CNO}^{\mathrm{c}}$ \\
\hline CyCyLa & $\mathrm{C}_{31} \mathrm{H}_{58} \mathrm{O}_{6}$ & 544 & $28: 00: 00$ & 8.97 \\
CyCLa & $\mathrm{C}_{33} \mathrm{H}_{62} \mathrm{O}_{6}$ & 572 & $30: 00: 00$ & 29.93 \\
CCLa & $\mathrm{C}_{35} \mathrm{H}_{66} \mathrm{O}_{6}$ & 600 & $32: 00: 00$ & 89.87 \\
CLaLa & $\mathrm{C}_{37} \mathrm{H}_{70} \mathrm{O}_{6}$ & 628 & $34: 00: 00$ & 95.27 \\
LaLaLa & $\mathrm{C}_{39} \mathrm{H}_{74} \mathrm{O}_{6}$ & 656 & $36: 00: 00$ & 100.00 \\
LaLaM & $\mathrm{C}_{41} \mathrm{H}_{78} \mathrm{O}_{6}$ & 684 & $38: 00: 00$ & 82.98 \\
LaMM & $\mathrm{C}_{43} \mathrm{H}_{82} \mathrm{O}_{6}$ & 712 & $40: 00: 00$ & 50.02 \\
LaLaO & $\mathrm{C}_{45} \mathrm{H}_{84} \mathrm{O}_{6}$ & 738 & $42: 01: 00$ & 13.13 \\
LaMP & $\mathrm{C}_{45} \mathrm{H}_{86} \mathrm{O}_{6}$ & 740 & $42: 00: 00$ & 24.01 \\
LaMO & $\mathrm{C}_{47} \mathrm{H}_{88} \mathrm{O}_{6}$ & 766 & $44: 01: 00$ & 7.75 \\
LaPP & $\mathrm{C}_{47} \mathrm{H}_{90} \mathrm{O}_{6}$ & 768 & $44: 00: 00$ & 8.05 \\
OMM & $\mathrm{C}_{49} \mathrm{H}_{92} \mathrm{O}_{6}$ & 794 & $46: 01: 00$ & 3.97 \\
LaOO & $\mathrm{C}_{51} \mathrm{H}_{94} \mathrm{O}_{6}$ & 820 & $48: 02: 00$ & 1.75 \\
\hline
\end{tabular}

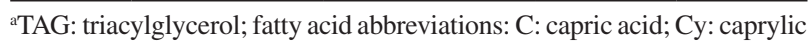
acid; La: lauric acid; M: myristic acid; O: oleic acid; P: pamitic acid; ${ }^{\mathrm{b}} \mathrm{CN} / \mathrm{DB}$ : carbon number/number of double bonds of the three fatty acid moieties, "relative percentage.

plays a central role in mass spectrometry and it is required for correct interpretation of MS data. In Figure 2 the fragmentation of the $\left[\mathrm{TAG}+\mathrm{NH}_{4}\right]^{+}$of $870.9 \mathrm{~m} / \mathrm{z}$ was observed. The main diacylglycerols were found LnP, LP $(573.6 \mathrm{~m} / \mathrm{z})$; OPo, LP $(575.6 \mathrm{~m} / \mathrm{z})$; and LLn $(597.6 \mathrm{~m} / \mathrm{z})$; these results are according to Holcapek et al. ${ }^{28}$ which shows that these fragments correspond to the $\left[\mathrm{LLnP}+\mathrm{NH}_{4}\right]^{+}$, being LLnP the TAG composed by linoleic acid (L), linolenic acid (Ln) and palmitic acid (P). 

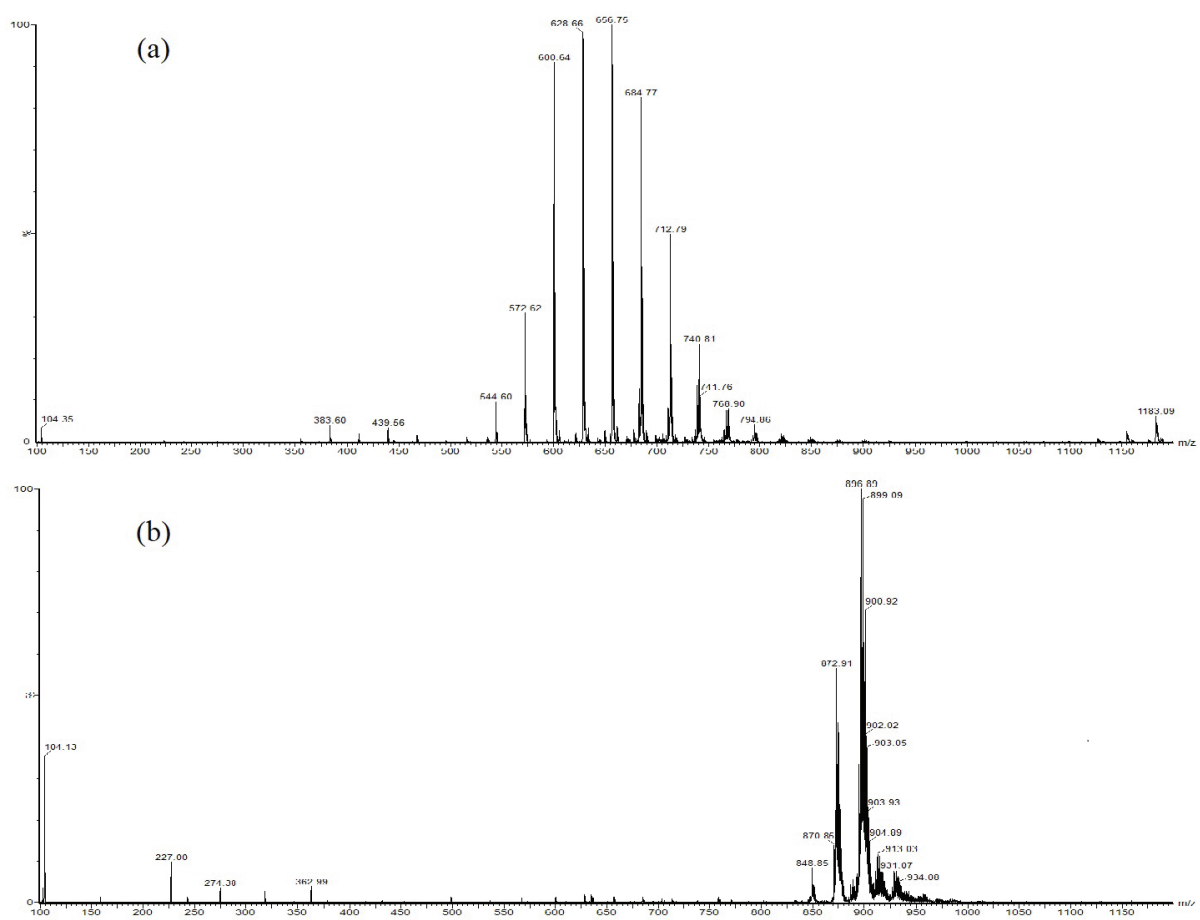

Figure 1. Lipid profile of (a) coconut oil (CNO) and (b) soybean oil (SOO) obtained by ESI(+)-MS.

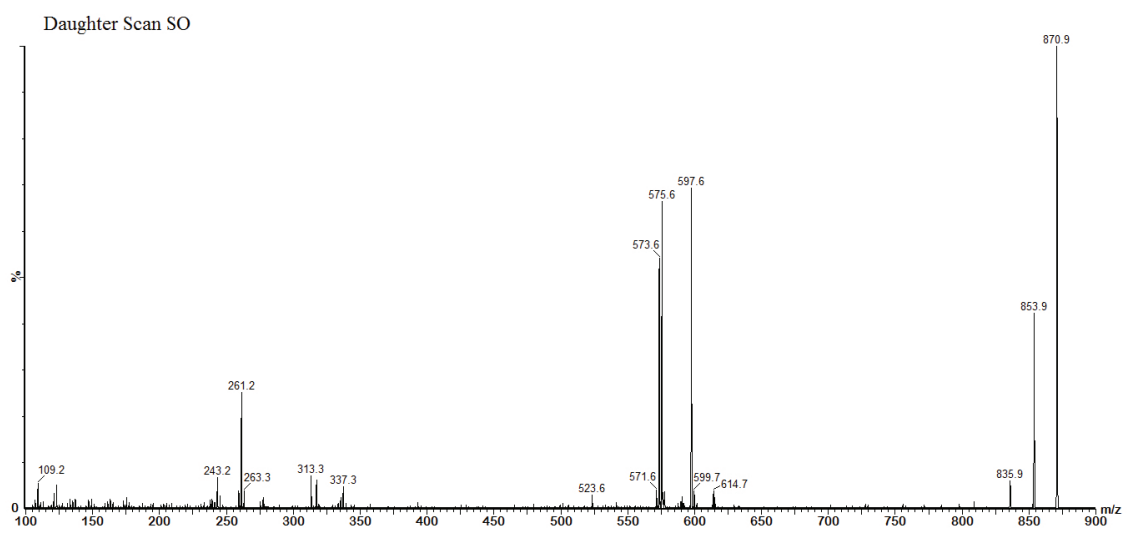

Figure 2. Daughter scan of $\left[\mathrm{LLnP}+\mathrm{NH}_{4}\right]^{+}(870.9 \mathrm{~m} / \mathrm{z})$ from SOO.

The lipid marker (LLnP in its ammonium adduct form) was further used to quantify possible adulteration of commercial coconut oil samples. For this, intentional adulterations of $\mathrm{CNO}$ by $\mathrm{SOO}$ were performed with the following percentages of SOO: 0, 2, 5, 10, 15, 20, 30, 50,70 and $100 \%(\mathrm{v} / \mathrm{v})$. These mixtures were analyzed by direct infusion ESI-MS, and an analytical curve focusing on the lipid marker $\left[\mathrm{LLnP}+\mathrm{NH}_{4}\right]^{+}(870.9 \mathrm{~m} / \mathrm{z})$ was constructed through its intensity versus $\mathrm{SOO}$ percentage added to $\mathrm{CNO}$.

Other lipid markers, such as 860.7, 865.2, 873.4, 880.0, 912.0 and $915.0 \mathrm{~m} / z$, from $\left[\mathrm{TAG}+\mathrm{NH}_{4}\right]^{+}$were found since the regions of the TAG predominance in the spectra of the $\mathrm{CNO}$ and $\mathrm{SOO}$ were different. For $\mathrm{CNO}$, the region of TAG predominance was $500-850 \mathrm{~m} / \mathrm{z}$, while for SOO the region was $800-1000 \mathrm{~m} / z$. However, the $870.9 \mathrm{~m} / z$ lipid marker [LLnP $\left.+\mathrm{NH}_{4}\right]^{+}$was selected because it was the marker with the higher intensity among all markers found.

Moreover, the LLnP is composed with linoleic (L), linolenic (Ln) and palmitic (P) acids and the Ln fatty acid was only found in SOO. Besides, the L fatty acid is present in higher percentages in SOO than in $\mathrm{CNO}$ (approximately 54 and $1 \%$, respectively, Table 1). In addition, other authors also found this same TAG in soybean oil. ${ }^{28,29}$

Other oils that may have the $870.9 \mathrm{~m} / z$ [TAG $\left.+\mathrm{NH}_{4}\right]^{+}$ are linseed oil and rapeseed oil. ${ }^{28,29}$ However, intentional adulteration usually occur with addition of lower price oils and fats, ${ }^{6}$ such as soybean oil ${ }^{7}$ and that oils are more expensive than soybean oil. 


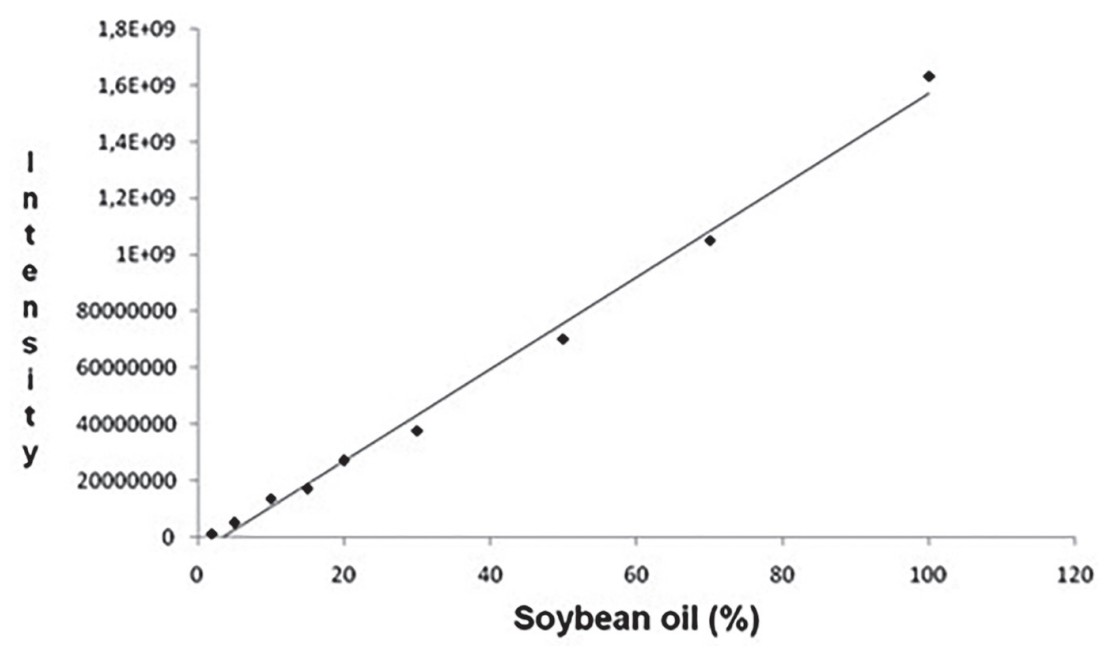

Figure 3. Analytical curve of $870.9 \mathrm{~m} / z\left[\mathrm{LLnP}+\mathrm{NH}_{4}\right]^{+}$intensity versus $\mathrm{SOO}(\%)$.

The calibration curve was obtained in triplicate by linear regression and is presented in Figure 3. The determination coefficient $\left(\mathrm{R}^{2}\right)$ was 0.994 , indicating that the model fit the data very well. The regression equation was $y=2.10^{7} x-6.10^{7}$. From this equation, the percentage of SOO intentionally added to $\mathrm{CNO}$ can be quantified, and the adulteration can be evaluated from $2 \%$ of SOO.

Five commercial coconut oil samples (C1-C5) were analyzed to quantify possible adulterations of coconut oil samples with the addition of SOO. According to this lipid marker-ESI(+)-MS proposed method, no adulteration with SOO was found in the analyzed samples.

\section{Conclusions}

The lipid marker-ESI(+)-MS method used in this work is simple, fast, sensitive, and conclusive, and can be used to qualify and quantify the insertion of SOO (from $2 \%$ ) to CNO by monitoring a lipid marker found only in SOO. Many analytical methods have been developed to identify and quantify adulteration in oils, but some are not conclusive when performed solely, such as GC-FID analysis. The detection of a small adulteration of CNO by SOO was no conclusive and difficult to observe in GC-FID solely. Finally, the lipid marker-ESI(+)-MS method is of great importance since intentional adulterations using large amounts of SOO in CNO do not occur in the oil industry because such fraud could be easily detect since both oils have different characteristics.

\section{Acknowledgments}

The authors thank the Fundação Araucaria, CAPES and CNPQ for financial support.

\section{References}

1. Chan, E.; Elevitch, C. R. In Traditional Trees of Pacific Islands: Their Culture, Environment, and Use; Elevitch, C. R., ed.; Permanent Agriculture Resources: Holualoa, Hawai, 2006; p. 227-302.

2. DebMandal, M.; Mandal, S.; Asian Pac. J. Trop. Med. 2011, 4, 241.

3. Bhatnagar, A. S.; Kumar, P. K. P.; Hemavathy, J.; Krishna, A. G. G.; J. Am. Oil Chem. Soc. 2009, 86, 991.

4. Ribeiro, G. T.; Braz. J. Surg. Clin. Res. 2017, 18, 109.

5. Gopala, K. A. G.; Raj, G.; Bhatnagar, A. S.; Kumar, P.; Chandrashekar, P.; Indian Coconut J. 2010, 15.

6. Xu, B.; Li, P.; Ma, F.; Wang, X.; Matthäus, B.; Chen, R.; Yang, Q.; Zhang, W.; Zhang, Q.; Food Chem. 2015, 178, 128.

7. Aued-Pimentel, S.; Castro, F. D.; de Sousa, R. J.; Mello, M. R. P. A.; Abe-Matsumoto, L. T.; J. Agric. Life Sci. 2015, 2, 76.

8. United States Department of Agriculture (USDA); Oilseeds: World Markets and Trade; available at: https://www.fas.usda. gov/data/oilseeds-world-markets-and-trade, accessed on March 12, 2018.

9. Pizzo, J. S.; Galuch, M. B.; Santos, P. D. S.; Santos, O. O.; Visentainer, L.; Eberlin, M. N.; Visentainer, J. V.; J. Braz. Chem. Soc. 2018, 29, 2457.

10. Galuch, M. B.; Carbonera, F.; Magon, T. F. S.; da Silveira, R.; dos Santos, P. D. S.; Pizzo, J. S.; Santos, O. O.; Visentainer, J. V.; J. Braz. Chem. Soc. 2018, 29, 631.

11. Silveira, R.; Vágula, J. M.; Figueiredo, I. L.; Claus, T.; Galuch, M. B.; Santos Jr., O. O.; Visentainer, J. V.; Food Res. Int. 2017, 102,43 .

12. Mansor, T. S. T.; Man, Y. B. C.; Rohman, A.; Food Anal. Methods 2011, 4, 365.

13. Manaf, M. A.; Man, Y. B. C.; Hamid, N. S. A.; Ismail, A.; Abidin, S. Z.; J. Food Lipids 2007, 14, 111. 
14. Marina, A. M.; Man, Y. B. C.; Nazimah, S. A. H.; Amin, I.; J. Food Lipids 2009, 16, 50.

15. Marina, A. M.; Man, Y. B. C.; Amin, I.; J. Am. Oil Chem. Soc. 2010, 87, 263

16. Cabral, E. C.; da Cruz, G. F.; Simas, R. C.; Sanvido, G. B.; Gonçalves, L. V.; Leal, R. V. P.; da Silva, R. C. F.; da Silva, J. C. T.; Barata, L. E. S.; da Cunha, V. S.; de França, L. F.; Daroda, R. J.; de Sá, G. F.; Eberlin, M. N.; Anal. Methods 2013, 5, 1385.

17. Catharino, R. R.; Haddad, R.; Cabrini, L. G.; Cunha, I. B. S.; Sawaya, A. C. H. F.; Eberlin, M. N.; Anal. Chem. 2005, 77, 7429.

18. Souza, R. C. Z.; Eiras, M. M.; Cabral, E. C.; Barata, L. E. S.; Eberlin, M. N.; Catharino, R. R.; Anal. Lett. 2011, 44, 2417.

19. Bligh, E. G.; Dyer, W. J.; Can. J. Biochem. Physiol. 1959, 37, 911.

20. Hartman, L.; Lago, R. C.; Lab. Pract. 1973, 22, 475.

21. Maia, E. L.; Rodriguez-Amaya, D. B.; Rev. Inst. Adolfo Lutz 1993, 53, 27.

22. Hammer, Ø.; Harper, D. A. T.; Ryan, P. D.; Palaeontol. Electronica 2001, 4, 9.
23. Codex Alimentarius; Standard for Named Vegetable Oils, Codex Stan 210-1999; Food and Agriculture Organization of the United States (FAO), World Health Organization (WHO), 2015, p. 1-13.

24. Kris-Etherton, P.; Taylor, D. S.; Yu-Poth, S.; Huth, P.; Moriarty, K.; Fishell, V.; Hargrove, R. L.; Zhao, G.; Etherton, T. D.; Am. J. Clin. Nutr. 2000, 71, 179S.

25. Gebauer, S. K.; Psota, T. L.; Harris, W. S.; Kris-Etherton, P. M.; Am. J. Clin. Nutr. 2006, 83, $1526 \mathrm{~S}$.

26. Catharino, R. R.; Haddad, R.; Cabrini, L. G.; Cunha, I. B. S.; Sawaya, A. C. H. F.; Eberlin, M. N.; Anal. Chem. 2005, 77, 7429.

27. Saraiva, S. A.; Cabral, E. C.; Eberlin, M. N.; Catharino, R. R.; J. Agric. Food Chem. 2009, 57, 4030.

28. Holcapek, M.; Jandera, P.; Zderadicka, P.; Hrubá, L.; J. Chromatogr. A 2003, 1010, 195.

29. Fasciotti, M.; Pereira Netto, A. D.; Talanta 2010, 81, 1116.

Submitted: November 26, 2018

Published online: March 14, 2019 